\title{
Pengaruh Badan Usaha Milik Desa (Bumdes) Terhadap Kesejahteraan Masyarakat Di Desa Pandansari Kecamatan Sine Kabupaten Ngawi
}

\author{
Sangrila Puspita Dewi \\ Fakultas Ilmu Sosial dan Ilmu Politik, Universitas Soerjo Ngawi, Jl. Cepu No.km. 3, Ngawi, 63218 \\ E-mail: sangrilapuspita92@gmail.com
}

\begin{abstract}
The objectives of this study are (1) to describe the Village Owned Enterprises (BUMDES) in Pandansari Village, Sine District, Ngawi Regency; (2) to describe the Community Welfare in Pandansari Village, Sine District, Ngawi Regency; (3) to determine the influence of Village-Owned Enterprises (BUMDES) on Community Welfare in Pandansari Village, Sine District, Ngawi Regency. The population in this study were residents or community members who were members of the Bansdes Pandansari Village, Sine District, Ngawi Regency, amounting to 75 people. Data collection techniques in this study were questionnaires and documentation. While the data analysis techniques in this study are quantitative descriptive analysis, simple regression analysis and hypothesis testing (t test). The findings of this study are (1) Village-Owned Enterprises (BUMDES) in Pandansari Village, Sine District, Ngawi Regency are classified as good; (2) Community Welfare in Pandansari Village, Sine District, Ngawi Regency is classified as Good; (3) There is an influence of Village-Owned Enterprises (BUMDES) on Community Welfare in Pandansari Village, Sine District, Ngawi Regency.
\end{abstract}

Keywords—: village-owned enterprise; community welfare.

\section{PENDAhuluaN}

Desa merupakan unit terkecil dari negara yang terdekat dengan masyarakat dan secara riil langsung menyentuh kebutuhan masyarakat untuk disejahterakan. Menurut Undang-Undang Nomor 6 Tahun 2014 Desa adalah kesatuan masyarakat hukum yang memiliki batas wilayah, yang berwenang untuk mengatur dan mengurus urusan pemerintahan, kepentingan masyarakat setempat berdasarkan prakarsa masyarakat, hak asal usul, dan/atau hak tradisional yang diakui dan dihormati dalam sistem pemerintahan Negara Kesatuan Republik Indonesia .

Sebagai wakil negara, desa wajib melakukan pembangunan baik pembangunan fisik maupun pembanguan sumber daya manusia, sebagai upaya peningkatan kualitas hidup dan kehidupan untuk sebesar-besarnya kesejahteraan masyarakat desa. Menurut Saeful Bachrein (2010:133-149), pertumbuhan ekonomi desa seringkali dinilai lambat dibandingkan pembangunan ekonomi perkotaan. Untuk meningkatkan hal tesebut dibutuhkan dua pendekatan yaitu: (1) Kebutuhan masyarakat dalam melakukan upaya perubahan dan mencegah hal-hal yang tidak diinginkan, dan (2) Political will dan kemampuan pemerintah desa bersama masyarakat dalam mengimplementasikan perencanaan pembangunan yang sudah disusun.

Salah satu upaya yang bisa dilakukan adalah dengan mendorong gerak ekonomi desa melalu kewirausahaan desa, dimana kewirausahaan desa menjadi strategi dalam pengembangan dan pertumbuhan kesejahteraan. Kewirausahaan desa ini dapat diwadahi dalam Badan Usaha Milik Desa (BUMDes) yang dikembangkan oleh pemerintah maupun masyarakat desa .

Badan Usaha Milik Desa (BUMDes) merupakan lembaga usaha desa yang dikelola oleh masyarakat dan pemerintahan desa dalam upaya memperkuat perekonomian desa dan dibentuk berdasarkan kebutuhan dan potensi desa. BUMDes merupakan pilar kegiatan ekonomi di desa yang berfungsi sebagai lembaga sosial (social institution) dan komersial (commercialinstitution). Landasan hukum yang melandasi berdirinya Badan Usaha Milik Desa (BUMDes) ini antara lain adalah Undang-Undang Nomor 6 Tahun 2014 tentang Desa dan Peraturan Pemerintah Nomor 43 Tahun 2014 tentang Peraturan Pelaksanaan Undang-Undang Nomor 6 Tahun 2014 tentang Desa.

Berdasarkan Perturan Pemerintah Nomor 43 Tahun 2014 tentang Peraturan Pelaksanaan Undang-Undang Nomor 6 Tahun 2014 tentang Desa, maksud dari pendirian Badan Usaha Milik Desa (BUMDes) tersebut adalah "sebagai usaha desa yang dimaksud untuk menampung seluruh peningkatan pendapatan desa, baik yang berkembang menurut adat istiadat maupun kegiatan perekonomian yang diserahkan untuk dikelola oleh masyarakat dari program proyek pemerintah dan pemerintah daerah."

Tujuan dari pendirian Badan Usaha Milik Desa (BUMDes) adalah sebagai upaya untuk peningkatan pendapatan asli daerah dan pedesaan dengan meningkatkan kapasitas masyarakat dalam merencanakan dan mengelola pembangunan perekonomian desa. Disamping itu pendirian Badan Usaha Milik Desa (BUMDes) ini mempunyai sasaran yaitu terlayaninya masyarakat desa dalam mengembangkan usaha ekonomi produktif serta tersedianya beragam media usaha dalam mengurangi dan meningkatkan kesejahteraan masyarakat.

Pendirian Badan Usaha Milik Desa (BUMDes) adalah merupakan per-wujudan dari pengelolaan ekonomi produktif desa yang dilakukan secara kooperatif, partisipatif, emansipatif, transparasi, akuntabel, sustainable. Oleh karena itu perlu upaya serius untuk menjadikan pengelolaan Badan Usaha Milik Desa (BUMDes) tersebut dapat berjalan secara efektif, efesien, 
Website : http://sosial.unmermadiun.ac.id/index.php/sosial

proporsional, dan mandiri. Untuk mencapai tujuan Badan Usaha Milik Desa (BUMDes) dilakukan dengan cara memenuhi kebutuhan produktif dan konsumtif masyarakat melalui pelayanan distribusi barang dan jasa yang dikelola masyarakat dan pemerintah desa.

BUMDes adalah badan usaha yang seluruh atau sebagian besar modalnya dimiliki oleh desa melalui penyertaan langsung yang berasal dari kekayaan desa yang dipisahkan guna mengelola aset, jasa pelayanan, dan usaha lain untuk sebesar-besarnya kesejahteraan masyarakat desa.. Hal tersebut semakin didukung oleh pemerintah dengan keluarnya Peraturan Pemerintah Nomor 47 Tahun 2015 yang menyebutkan bahwa desa mempunyai wewenang untuk mengatur sumber daya dan arah pembangunan.

Hal tersebut membuka peluang desa untuk otonom dalam pengelolaan baik kepemerintahan maupun sumber daya ekonominya. Sebagai unit terkecil dari negara, desa secara riil langsung menyentuh kebutuhan masyarakat. Indonesia memiliki 74.093 desa (BPS, 2013), dimana lebih dari 32 ribu desa masuk dalam kategori desa tertinggal. Salah satu strategi untuk menanggulangi hal ini adalah mewujudkan kewirausahaan desa dimana sumber daya dan fasilitas yang disediakan secara spontan oleh komunitas masyarakat desa untuk merubah kondisi sosisal pedesaan. Terbitnya Undang-Undang Nomor 6 Tahun 2014 dan terbitnya Peraturan Pemerintah Nomor 47 Tahun 2015 menghendaki adanya desa yang mandiri dan otonom dalam pengelolaan sumber daya yang dimilikinya dimana BUMDes diharapkan berperan dalam peningkatan perekonomian pedesaan.

Di sisi lain, desa memiliki keterbatasan. Dalam hal ini, modal sosial desa lebih besar daripada modal ekonomi. Modal sosial yang dimaksud adalah ikatan sosial, jembatan sosial, dan jaringan sosial. Modal sosial ini bersifat parokial (terbatas) menjadi modal sosial yang paling dangkal dan tidak mampu memfasilitasi pembangunan ekonomi.

Berdasarkan uraian latar belakang di atas, maka masalah dalam penelitian ini dapat dirumuskan sebagai berikut: Apakah ada pengaruh peranan BumDesa terhadap kesejahteraan masyarakat di Desa Pandansari Kecamatan Sine Kabupaten Ngawi?

Penelitian ini bertujuan untuk (1) mendeskripsikan atau menggambarkan peranan BumDesa di Desa Pandansari Kecamatan Sine Kabupaten Ngawi; (1) mendeskripsikan atau menggambarkan kesejahteraan masyarakat di Desa Pandansari Kecamatan Sine Kabupaten Ngawi; dan (3) untuk mengetahui pengaruh peranan BumDesa terhadap kesejahteraan masyarakat di Desa Pandansari Kecamatan Sine Kabupaten Ngawi.

\section{METODE PENELITIAN}

Penelitian ini termasuk jenis penelitian asosiatif (hubungan). Menurut Sugiyono (2016:11) Penelitian asosiatif adalah penelitian yang bertujuan untuk mengetahui hubungan antara dua variabel atau lebih. Penelitian ini bermaksud untuk menguji pengaruh peranan BumDesa terhadap kesejahteraan masyarakat di Desa Pandansari Kecamatan Sine Kabupaten Ngawi.

Variabel bebas menurut Hadari Nawawi 2005:57) adalah "Sejumlah gejala, faktor, atau unsur yang menentukan atau mempengaruhi adanya atau munculnya gejala atau faktor atau unsur lainnya.“ Pada penelitian ini yang menjadi variabel bebas adalah Bumdes. Indikatornya peranan BUMDES adalah sebagai berikut:

a. Meningkatkan perekonomian desa

b. Meningkatkan pendapatan asli desa (PAD)

c. Meningkatkan pengelolaan potensi desa sesuai dengan kebutuhan ma-syarakat

d. Menjadi tulang punggung pertumbuhan dan pemerataan ekonomi desa.

Variabel terikat menurut Hadari Nawawi (2005:58) adalah: "Sejumlah gejala atau faktor atau unsur yang ada atau muncul dipengaruhi atau ditentukan oleh adanya variabel bebas." Pada penelitian ini yang menjadi variabel terikat adalah kesejahteraan masyarakat. Sedangkan yang menjadi indikator kesejahteraan masyarakat sebagai berikut:

a. Tingkat pendapatan keluarga

b. Komposisi pengeluaran rumah tangga dengan membandingkan penge-luaran untuk pangan dengan non-pangan

c. Tingkat pendidikan keluarga

d. Tingkat kesehatan keluarga

e. Kondisi perumahan serta fasilitas yang dimiliki dalam rumah tangga

Populasi dalam penelitian ini adalah penduduk atau warga masyarakat yang menjadi anggota Bumdes Desa Pandansari Kecamatan Sine Kabupaten Ngawi yang berjumlah 75 orang. Mengingat jumlah populasi tidak terlalu besar, maka tidak perlu diambil sampel penelitian. Hal ini sesuai dengan pendapat Suharsimi Arikunto (2002:107) yang menyatakan sebagai berikut: "Apabila subyeknya lebih dari 100 (seratus) orang maka sebaiknya diambil antara 10\% - 15\% atau 20\% - 25\% atau lebih, sedangkan jika subyeknya kurang dari 100 orang, maka sebaiknya diambil seluruhnya”. Karena jumlah populasi dalam penelitian ini sejumlah 75 orang berarti kurang dari 100, maka tidak perlu diambil sampel sehingga penelitian ini merupakan penelitian populasi atau survei dengan responden sejumlah 75 orang.

Suharsimi Arikunto (2002:107), menjelaskan yang dimaksud dengan sumber data adalah "Subyek dari mana data dapat diperoleh". Dalam penelitian ini sumber datanya dibedakan atas dua hal yaitu data primer dan data sekunder. Teknik merupakan cara tertentu yang khusus untuk mencari tujuan tertentu. Suatu teknik terdiri dari kegiatan-kegiatan yang teratur dan beraturan, berdasarkan ketentuan-ketentuan sehingga merupakan cara untuk mencapai tujuan. Agar diperoleh data yang benarbenar dapat mendukung dalam pemecahan masalah maka teknik pengumpulan data yang digunakan adalah kuesioer dan dokumentasi. 
Berdasarkan tujuan dan jenis penelitian yang dikemukakan, maka analisis data yang digunakan dalam penelitian ini adalah analisa deskriptif kuantitatif. Sedangkan teknik analisa data menggunakan analisa regresi linier sederhana yang bertujuan untuk mengetahui pengaruh variabel bebas terhadap variabel terikat. Uji hipotesis dalam penelitian ini menggunakan uji t.

\section{III.HASIL DAN PEMBAHASAN}

\section{A. Uji Validitas dan Reliabilitas}

Pengolahan data dilakukan menggunakan program statistik komputer release SPSS 16.0. Hasil pengolahan data untuk uji validitas dan reliabilitas menunjukkan bahwa semua item pernyataan untuk variabel bumdes (X) dan kesejahteraan masyarakat (Y) dengan 75 responden mempunyai korelasi lebih besar dari $r$ tabel 0,227 dan cronbach alphanya $>0,60$. Dengan demikian dapat disimpulkan semua item pernyataan variabel bumdes dan kesejahteraan masyarakat valid dan reliabel sehingga dapat digunakan untuk pengujian selanjutnya.

\section{B. Analisa Deskriptif}

Data hasil penelitian tentang Peranan Badan Usaha Milik Desa (Bumdes) di Desa Pandansari Kecamatan Sine Kabupaten Ngawi dapat dilihat pada tabel 1 berikut ini.

Tabel 1. Klasifikasi Variabel Tentang Peranan BUMDES Desa Pandansari Kecamatan Sine Kabupagen Ngawi

\begin{tabular}{|l|c|c|}
\hline \multicolumn{1}{|c|}{ Kategori } & $\begin{array}{c}\text { Jumlah } \\
\text { Responden }\end{array}$ & $\begin{array}{c}\text { Prosentase } \\
(\%)\end{array}$ \\
\hline Sangat Baik & 48 & 64.0 \\
\hline Baik & 13 & 17.3 \\
\hline Cukup & 6 & 8.0 \\
\hline Kurang & 4 & 5.3 \\
\hline Sangat Kurang & 4 & 5.3 \\
\hline Jumlah & 75 & 100.0 \\
\hline Sumber data : data diolah, 2020 & & \\
\hline
\end{tabular}

Dari tabel tersebut di atas dapat diketahui bahwa dari 75 responden atau $100 \%$, terdapat 48 responden atau $64 \%$ termasuk dalam kategori sangat baik, sebanyak 13 responden atau 17,3\% termasuk dalam kategori baik, sebanyak 6 responden atau $8 \%$ dalam kategori cukup dan kurang dan terdapat 4 orang atau 5,3\% masing-masing dalam kategori kurang dan sangat kurang. Berdasarkan data di atas, maka dapat disimpulkan bahwa peranan Badan Usaha Milik Desa di Desa Pandansari Kecamatan Sine Kabupagen Ngawi adalah sangat baik.

Data hasil penelitian tentang Kesejahteraan Masyarakat di Desa Pandansari Kecamatan Sine Kabupaten Ngawi dapat dilihat pada tabel 2 berikut ini.

Tabel 2. Klasifikasi Variabel Tentang Kesejahteraan Masyarakat Desa Pandansari Kecamatan Sine Kabupagen Ngawi

\begin{tabular}{|l|c|c|}
\hline Kategori & $\begin{array}{c}\text { Jumlah } \\
\text { Responden }\end{array}$ & $\begin{array}{c}\text { Prosentase } \\
(\%)\end{array}$ \\
\hline Sangat Baik & 54 & 72.0 \\
\hline Baik & 8 & 10.7 \\
\hline Cukup & 6 & 8.0 \\
\hline Kurang & 4 & 5.3 \\
\hline Sangat Kurang & 3 & 4.0 \\
\hline Jumlah & 75 & 100.0 \\
\hline Sumber data : data diolah, 2020 &
\end{tabular}

Dari tabel tersebut diatas dapat diketahui bahwa dari 75 responden atau $100 \%$ terdapat 54 responden atau $72 \%$ termasuk dalam kategori sangat baik, sebanyak 8 responden atau 10,7\% termasuk dalam kategori baik, sebanyak 6 responden atau $8 \%$ dalam kategori cukup, sebanyak 4 responden atau 5,3\% dalam kategori kurang, sedangkan yang termasuk dalam katetori sangat kurang sebanyak 3 responden atau 4\%. Berdasarkan data di atas, maka dapat disimpulkan bahwa Kesejahteraan Masyarakat Desa Pandansari Kecamatan Sine Kabupagen Ngawi adalah sangat baik.

\section{Analisa Regresi Sederhana}

Suatu hasil dan analisis regresi linear sederhana akan dapat dijadikan sebagai dasar pengambilan kesimpulan jika telah memenuhi beberapa asumsi yang disebut dengan asumsi klasik regresi linear berganda. Asumsi klasik regresi linear sederhana 
Website : http://sosial.unmermadiun.ac.id/index.php/sosial

meliputi uji normalitas, multikolinearitas dan heteroskedastisitas. Hasil uji normalitas, pengujian asumsi klasik dan analisa regresi linear sederhana adalah sebagai berikut:

\section{Uji Normalitas}

Uji statistik Kolmogorov-Smirnov (K-S) juga dilakukan pada uji normalitas, untuk lebih memastikan apakah data residual terdistribusi secara normal atau tidak. Kriteria pengambilan keputusan dalam uji Kolmogorov-Smirnov (Analisis Explore) yaitu jika signifikansi $>0,05$ maka data terdistribusi normal dan jika signifikansi $<0,05$ maka data tidak terdistribusi secara normal. Hasil uji normalitas dengan menggunakan uji Kolmogorov-Smirnov (Analisis Explore) dapat dilihat sebagai berikut:

\begin{tabular}{|l|c|}
\multicolumn{1}{|c|}{ Tabel 3. Uji Normalitas } \\
\hline Asymp.Sig. (2-tailed) & Unstandardized Residual \\
\hline Sumber data: data diolah, 2020 & 0,065 \\
\hline
\end{tabular}

Berdasarkan tabel 7 di atas dapat diketahui bahwa nilai signifikan Unstandardized Residual sebesar 0,065 lebih besar dari $\alpha=$ 0,05 , artinya variabel dalam penelitian ini berdistribusi normal.

\section{E. Uji Asumsi Klasik Heteroskedastisitas}

Pada pembahasan ini akan dilakukan uji heteroskedastisitas dengan menggunakan uji Spearman rho yaitu mengkorelasikan nilai residual dengan masing-masing variabel independen. Jika signifikansi korelasi kurang dari 0,05, maka pada model regresi terjadi masalah heteroskedastisitas.

\begin{tabular}{|l|c|}
\hline \multicolumn{1}{|c|}{ Tabel 4. Correlations } \\
\hline bumdes & Unstandardized Residual \\
\hline Sumber data: data diolah, 2020 & 0,344 \\
\hline
\end{tabular}

Berdasarkan tabel di atas, dapat diketahui nilai signifikan antara bumdes dengan Unstandardized residual sebesar 0,344. Karena nilai signifikansi korelasi lebih dari 0,05 maka dapat disimpulkan bahwa pada model regresi tidak ditemukan adanya masalah heteroskedastisitas.

\section{F. Uji Asumsi Klasik Multikolinearitas}

Uji multikolinieritas dilakukan dengan melihat nilai tolerance dan VIF. Variabel independen dinyatakan terbebas dari masalah multikolinieritas bila nilai tolerance $>0,1$ atau sama dengan nilai VIF < 10. (Ghozali, 2016:154).

Tabel 5. Coefficients

\begin{tabular}{|l|c|c|}
\hline \multirow{2}{*}{ Model } & \multicolumn{2}{|c|}{ Collinearity Statistics } \\
\cline { 2 - 3 } & Tolerance & VIF \\
\hline bumdes & 1,000 & 1,000 \\
\hline
\end{tabular}

Sumber data: data diolah, 2020

Dari tabel 9 di atas, dapat diketahui bahwa nilai VIF variabel bumdes sebesar 1,000 Karena nilai VIF kurang dari 10, maka dapat disimpulkan bahwa pada model regresi tidak ditemukan adanya masalah multikolinearitas.

\section{G. Analisis Regresi Linier Sederhana}

Hasil perhitungan analisa regresi sederhana antara variabel bumdes (X) sebagai variabel independent terhadap kesejahteraan masyarakat pada sebagai variabel dependent (Y) dapat dilihat pada tabel di bawah ini.

Tabel 6. Hasil Analisis Regresi Linier Sederhana

\begin{tabular}{|l|c|}
\hline \multicolumn{1}{|c|}{ Model } & Unstandardized Coefficients \\
\hline (Constant) & $-4,103$ \\
\hline bumdes & 1,454 \\
\hline
\end{tabular}

Berdasarkan tabel 10, maka model persamaan regresi linier berganda yang dihasilkan dalam penelitian ini adalah:

$$
\begin{aligned}
& \mathrm{Y}=\mathrm{a}+\mathrm{bX} \\
& \mathrm{Y}=-4,103+1,454 \mathrm{X}
\end{aligned}
$$

Intepretasi dari persamaan regresi linier berganda di atas dapat dijelaskan sebagai berikut:

1. Nilai konstanta $a=-4,103$, hal ini menunjukkan bahwa apabila variabel bumdes $(\mathrm{X})$ diabaikan dalam analisis, maka kesejahteraan masyarakat (Y) menjadi sebesar 4,103.

2. Nilai $\mathrm{b}=1,454$, hal ini menunjukkan apabila bumdes naik satu satuan, maka kesejahteraan masyarakat akan naik sebesar 1,454 . 
Website : http://sosial.unmermadiun.ac.id/index.php/sosial

\section{H. Pengujian Hipotesis}

Pengujian hipotesis dalam penelitian ini menggunakan uji t. Uji t digunakan untuk menguji signifikansi pengaruh masingmasing variabel bebas terhadap variabel terikat. Uji t dapat diukur dengan melihat nilai signifikansinya. Hipotesis diterima jika nilai signifikansi <0,05 dan hipotesis ditolak jika nilai signifikansi $>0,05$. Hasil uji hipotesis dapat dilihat pada tabel berikut ini.

Tabel 7. Hasil Analisis Uji t

\begin{tabular}{|l|c|c|}
\hline \multicolumn{1}{|c|}{ Model } & Nilai t hitung & Nilai Signifikan \\
\hline bumdes & 11,773 & 0,000 \\
\hline Sumber data : data diolah, 2020 &
\end{tabular}

Dari hasil perhitungan dalam tabel 11 dapat diketahui nilai $t_{\text {hitung }}$ untuk variabel Profesionalisme sebesar 11,773 lebih besar dari $\mathrm{t}_{\text {tabel }}=1,993$ dengan tingkat signifikan 0,000 atau 0\% maka berarti ada pengaruh yang signifikan bumdes terhadap kesejahteraan masyarakat di Desa Pandansari Kecamatan Sine Kabupaten Ngawi.

\section{IV.KESIMPULAN}

Kesimpulan penelitian ini adalah (1) Badan Usaha Milik Desa (BUMDES) di Desa Pandansari Kecamatan Sine Kabupaten Ngawi tergolong Baik; (2) Kesejahteraan Masayrakat di Desa Pandansari Kecamatan Sine Kabupaten Ngawi tergolong Baik; (3) Ada pengaruh Badan Usaha Milik Desa (BUMDES) terhadap Kesejahteraan Masyarakat di Desa Pandansari Kecamatan Sine Kabupaten Ngawi.

\section{UCAPAN TERIMAKASIH}

Penelitian ini dapat dilkasanakan dengan lancar berkat bantuan dari beberapa pihak. Pada kesempatan ini ucapan terima kasih disampaikan kepada Kepala Desa dan Pengurus dan Anggota BumDes Desa Pandansari Kecamatan Sine Kabupaten Ngawi yang telah membantu pelaksanaan penelitian. Ucapan terima kasih disampaikan juga kepada Rektor dan Jajaran Lembaga Penelitian Universitas Soerjo Ngawi yang telah member ijin penelitian.

\section{VI.DAFTAR PUSTAKA}

Buku :

Bachrein, Saeful. 2010. Pendekatan Desa Membangun di Jawa Barat: Strategi dan Kebijakan Pembangunan Perdesaan. Jawa Barat: Jurnal Analisis Kebijakan Pertanian. Vol 8/No.2/Juni 2010: 133-149.

Badan Pusat Statistik 2013.

Hadari Nawawi, 2005, Manajemen Sumber Daya Manusia Untuk Bisnis Yang Kompetitif, Cetakan Ke-4, Gajah Mada Univercity Press, Yogyakarta.

Hadari Nawawi, 1999. Metode Penelitian Bidang Sosial, UGM Yogyakarta.

Kamus Besar Bahasa Indonesia, 1989. Jakarta: Balai Pustaka.

Koentjoroningrat, 2000, Metode Penelitian, Cet. 2, Jakarta: Ghalia Indonesia.

Rahmat J. 2001.Psikologi Komunikasi, Cetakan ke 16, Bandung: PT. Remaja Rosdakarya.

Seyadi. 2003. Bumdes sebagai Alternatif Lembaga Keuangan Desa. Yogyakarta: UPP STM YKPN.

Soerjono Soekanto, 2009. Sosiologi Suatu Pengantar. Jakarta:PT. Raja Grafindo.

Suharsimi Arikunto, 2002, Prosedur Penelitian Suatu pendekatan Praktek, Edisi Revisi, Jakarta: Reneka Cipta.

Sugiyono. 2016. Metode Penelitian Kuantitatif, Bandung: Alfabeta.

Sutrisno Hadi. 1999. Statistika Jilid I, Fakultas Psikologi UGM, Yogyakarta.

\section{Peraturan Perundang-Undangan:}

Undang-Undang Nomor 6 Tahun 2014 tentang Desa

Perturan Pemerintah Nomor 43 Tahun 2014 tentang Peraturan Pelaksanaan Undang-Undang Nomor 6 Tahun 2014 tentang Desa.

Permendagri No. 4 Tahun 2015 tentang Badan Usaha Milik Desa Peraturan Daerah Kabupaten Lingga No. 3 Tahun 2015 tentang Pedoman Tata Cara Pembentukan dan Pengelolaan Badan Usaha Milik Desa. 